\section{MID WINTER WATERFOWL CENSUS AT POBITORA WILDLIFE SANCTUARY FOR THE YEAR 2000}

\section{Mrigen Barua}

Range Forest Officer, Assam Forest Department, M/s Cinderella Restaurant, Dr. R.P. Road, Ganeshgiri, Guwahati, Assam 781006, India.

Pobitora Wildlife Sanctuary $\left(26^{0} 12^{\prime} \mathrm{N}\right.$ to $26^{0} 15^{\prime} \mathrm{N}-92^{\circ} 2^{\prime}$ E to $92^{\circ} 5^{\prime}$ E) is an important site for migratory waterfowl of Assam. Each year during the month of October thousands of birds arrive here. The Sanctuary is situated $58 \mathrm{~km}$ east of Guwahati City, the capital of Assam. The entire area is flat with gentle incline from east to west. Flood waters from rivers Brahmaputra and Kolong, which pass through the Sanctuary's northern and southern sides flood the entire area. The water remains for the whole year in different lakes and swamps and make Pobitora the abode of migratory as well as resident birds.

The present land use pattern of the Sanctuary are: trees 13.09 per cent with the dominant species of Albizia procerea, Lagerstromea flosreganae, Salmalia malabaricum etc.; grasslands 72.25 per cent with dominant species of Erianthus ravanae, Saecharum elephantimus, Imparata cylindrica, Saecharum munja etc.; and the water body 14.61 per cent. Out of that total water body 10.61 per cent is perennial and 4 per cent is swampy. The aquatic vegetation are mainly Ipomea laptans, Learsia hexandra, Hanarthia compressa, Piltia stafistes, Lemnopanci costata, Eichhornia sp., Salvinia natans, Euryale ferox, Trapa natans etc.

We carried out the waterfowl count from 19 January to 22 January 2000. Though the terrain is flat we could cover only around 80 per cent of the total area due to many unavoidable reasons. The wetlands covered in our census were Tamulidova, Haduk, Jugdol, Tuplung-Jan, Solmari, Pagladova and Dholi.

In the morning hours of 19 January 2000 we covered Tamulidova, Haduk, and Jugdol beel and counted 8480 birds of 63 species. On the very next day we covered Tuplung-Jan and Solmari and counted 911 birds of 22 species, and 3154 birds of 32 species respectively. On 21 January we covered Pagladova where we counted 6288 birds of 48 species. On the very last day, on 22 January, we covered Dholi beel and counted 1694 birds of 30 species. Altogether 20,527 birds of 66 species were counted inside the Sanctuary.

Received 13 September 2000

Accepted 25 February 2001

\begin{tabular}{|c|c|c|}
\hline English Name & Scientific Name & Numbers \\
\hline \multicolumn{2}{|l|}{ Grebes } & 12 \\
\hline \multicolumn{3}{|l|}{ Pelicans } \\
\hline Spot-billed Pelican & Pelecanus philippensis & 16 \\
\hline \multicolumn{3}{|l|}{$\underline{\text { Cormorants and Darters }}$} \\
\hline Great Cormorant & Phalacrocorax carbo & 18 \\
\hline Little Cormorant & Phalacrocorax niger & 107 \\
\hline Darter & Anhingamelanogaster & 13 \\
\hline \multicolumn{3}{|l|}{ Herons and Egrets } \\
\hline Cinnamon Bittern & Ixobrychus cinnamomeus & 5 \\
\hline Black Bittern & Dupetor flavicollis & 13 \\
\hline Black-crowned Night Heron & Nycticorax nycticorax & 131 \\
\hline Indian Pond Heron & Ardeola grayii & 368 \\
\hline Cattle Egret & Bubulcus ibis & 474 \\
\hline Green-backed Heron & Butorides striatus & 40 \\
\hline Little Egret & Egretta garzetta & 415 \\
\hline Intermediate Egret & Mesophoyx intermedia & 82 \\
\hline Great Egret & Casmerodius albus & 28 \\
\hline Purple Heron & Ardea purpurea & 114 \\
\hline Grey Heron & Ardea cinerea & 105 \\
\hline White-bellied Heron & Ardea insignis & 14 \\
\hline \multicolumn{3}{|l|}{$\underline{\text { Storks }}$} \\
\hline$\overline{\text { Asian Open-billed Stork }}$ & Anastomus oscitans & 556 \\
\hline Black Stork & Ciconia niger & 8 \\
\hline Black-necked Stork & Ephippiorhynchus asiaticus & 16 \\
\hline Lesser Adjutant-Stork & Leptoptilos javanicus & 42 \\
\hline Greater Adjutant-Stork & Leptoptilos dubius & 5 \\
\hline$\frac{\text { Ibis and Spoonbills }}{\text { Asian White Ibis }}$ & Threskiornis melanocephalus & 28 \\
\hline \multicolumn{3}{|l|}{ Geese and Ducks } \\
\hline Fulvous Whistling-Duck & Dendrocygna bicolor & 18 \\
\hline Lesser Whistling-Duck & Dendrocygnajavanica & 5408 \\
\hline Greylag Goose & Anser anser & 38 \\
\hline Ruddy Shelduck & Tadorna ferruginea & 36 \\
\hline Cotton Pygmy-Goose & Nettapus coromandelianus & 22 \\
\hline Eurasian Wigeon & Anas penelope & 120 \\
\hline Falcated Duck & Anas falcata & 10 \\
\hline Gadwall & Anas strepera & 158 \\
\hline Common Teal & Anas crecca & 4520 \\
\hline Mallard & Anas platyrhynchos & 222 \\
\hline Spot-billed Duck & Anas poecilorhycha & 80 \\
\hline Northern Pintail & Anas acuta & 4800 \\
\hline Garganey & Anas querquedula & 560 \\
\hline
\end{tabular}




\begin{tabular}{|c|c|c|}
\hline English Name & Scientific Name & Numbers \\
\hline Northern Shoveller & Anas clypeata & 74 \\
\hline Common Pochard & Aythya ferina & 286 \\
\hline Baer's Pochard & Aythya baeri & 68 \\
\hline Ferruginous Pochard & Aythya nyroca & 296 \\
\hline Tufted Pochard & Aythya fuligula & 70 \\
\hline \multicolumn{3}{|l|}{ Rails, Gallinules and Coots } \\
\hline Water Rail & Rallus aquaticus & 12 \\
\hline Brown Crake & Amaurornis akool & 32 \\
\hline White-breasted Waterhen & Amaurornis phoenicurus & 70 \\
\hline Water Cock & Gallicrex cinerea & 8 \\
\hline Common Moorhen & Gallinula chloropus & 58 \\
\hline Purple Swamphen & Porphyrio porphyrio & 9 \\
\hline Common Coot & Fulica atra & 16 \\
\hline \multicolumn{3}{|l|}{ Finfoots and Jacanas } \\
\hline Pheasant-tailed Jacana & Hydrophasianus chirurgus & 74 \\
\hline Bronze-winged Jacana & Metopidius indicus & 228 \\
\hline \multicolumn{3}{|l|}{ Shore Birds - Waders } \\
\hline$\overline{\text { Greater Painted-Snipe }}$ & Rostratula benghalensis & 6 \\
\hline Northern Lapwing & Vanellus vanellus & 134 \\
\hline Grey-headed Plover & Vanellus cinereus & 60 \\
\hline Red-wattled Lapwing & Vanellus indicus & 45 \\
\hline Long-billed Plover & Charadrius placidus & 12 \\
\hline Little Ringed Plover & Charadrius dubius & 6 \\
\hline Common Redshank & Tringa totanus & 24 \\
\hline Marsh Sandpiper & Tringa stagnatilis & 125 \\
\hline Common Greenshank & Tringa nebularia & 31 \\
\hline Nordmann's Greenshank & Tringa guttifer & 5 \\
\hline Common Sandpiper & Actitis hypoleucos & 80 \\
\hline Pin-tailed Snipe & Gallinago stenura & 7 \\
\hline Common Snipe & Gallinago gallinago & 57 \\
\hline \multicolumn{3}{|l|}{ Gulls, Terns and Skimmers } \\
\hline River Tern & Sterna aurantia & 22 \\
\hline \multicolumn{3}{|l|}{ Additional species } \\
\hline Eurasian Marsh Harrier & Circus aeruginosus & 8 \\
\hline Osprey & Pandion haliaetus & 2 \\
\hline
\end{tabular}

Common names after Manakadan, et al. (1998).

\section{References}

Manakadan, R., J.C. Daniel, A.R. Rahmani, M. Inamdar and G. Ugra (1998). Standardised English common names of the birds of the Indian Subcontinent - a proposal. Buceros 3(2): 55pp. Bombay Natural History Society, Mumbai.

\section{THE INDIAN PANGOLIN (MANIS CRASSICAUDATA) IN THE CHAMBAL RAVINES OF ETAWAH}

\author{
Rajeev Chauhan and S. Narain
}

P.G. Department of Zoology, Janta College, Bakewar(Etawah), Uttar Pradesh 206124, India.

Little is known about the habits of the Indian Pangolin (Manis crassicaudata). Also called the Scaly Anteater, the pangolin has a wide distribution range in India (Prater, 1997). Pangolins are known to live in a variety of habitats ranging from deserts to rain forests (Prater, 1997). It is protected under Schedule I of the Indian Wildllife (Protection) Act, 1972.

In the Chambal ravines of Etawah District in southwestern Uttar Pradesh, we recorded a pangolin at Chakarnagar Village caught within the confines of a forest bungalow. Subsequent enquiries in the region proved that the species is fairly widely distributed in the ravines. Locals call the animal Sechi and we obtained reliable records of pangolin sightings from Bindwa, Sindaus and Bhareh villages (within an area of ca. $100 \mathrm{~km}^{2}$ ). The captured pangolin was measured to be $.91 \mathrm{~m}$ (3ft) in length. This fits within the range mentioned for the species by Prater (1997) and was probably not a full grown one.

Most villagers are familiar with the species and it seems to be common in the area. Pangolins are known to dig into houses with mud walls looking for food. A few villagers in the area kill the animals for food.

This is the first record of the pangolin from this area to the best of our knowledge. In Sabalgarh, Madhya Pradesh, one specimen was killed by the local people in the summer of 1984 and brought for identification (L.A.K. Singh, additional information). Dacoity in the Chambal ravines discourages wildlife enthusiasts from exploring the region. Further studies in the area on this elusive animal may provide useful information on its ecology and help in its conservation.

\section{Reference}

Prater, S.H. (1997). The book of Indian Animals (10th impression). Bombay Natural History Society, Mumbai, pp. 301-303. 